\title{
Composition and nutritional value for chickens and rats of seeds, cake and solvent meal from low-glucosinolate yellow-seeded spring rape and dark-seeded winter rape
}

\section{Stefania Smulikowska, Barbara Pastuszewska, Anna Ochtabińska and Anna Mieczkowska}

\author{
The Kielanowski Institute of Animal Physiologv and Nutrition, \\ Polish Academy of Sciences \\ 05-110 Jablonna, Poland
}

(Received 10 April 1998; accepted 22 September 1998)

\section{ABSTRACT}

The chemical composition and nutritional value of seeds, press-cakes and solvent meals produced under the same processing conditions from yellow-seeded spring Brassica rapa (YSR), and dark-seeded winter Brassica napus (DSR) rape were determined. Both varieties were of double low type. YSR products contained more protein and less fibre than DSR products, YSR meal contained less glucosinolates and had a similar concentration of amino acids $(\mathrm{g} / 16 \mathrm{gN})$ as DSR meal.

The nutritional value of DSR and YSR seeds and products was evaluated in two experiments on 261 broiler cockerels; press-cakes and solvent meals also in 4 experiments on 212 male rats. In chickens, the cnergy value of all YSR products was considerably higher than DSR due to greater fat digestibility. In rats, the nutritional value of protein (TD, BV, NPU) and energy value of YSR cake and meal were similar or marginally greater than of the respective DSR products.

Growth performance of chickens fed isoenergetic diets containing $20 \%$ of YSR and DSR meal did not differ from controls. In rats, feed intake and growth rate were negatively correlated with the glucosinolate level in the evaluated products and better on YSR than DSR cake and meal.

KEY WORDS: rapeseed dark-seeded, rapeseed yellow-seeded, chickens, rats, energy, protein

\section{INTRODUCTION}

The use of low-glucosinolate rapeseed oilmeal in diets for poultry and young pigs is limited by its high fibre content and low energy value. In Canada attempts have been made to improve the nutritional value of canola by breeding yellow-see- 
ded varieties of rape with thinner hulls and decreased fibre content (Słomiński, 1997). Also in Poland, a decrease of hull and fibre proportions in the seeds is considered to be an important objective of rapeseed breeding (Krzymański, 1993).

The yellow-seeded forms of rapeseed have greater protein and smaller crude fibre content, but their nutritional value determined using a variety of criteria was not consistently greater than that of dark-seeded ones (Słomiński et al., 1994,1995; Campbell et al., 1995; Ochodzki and Rakowska, 1996).

Since the nutritional value of both rapeseed cake and meal is greatly affected by the conditions of processing in an oil factory, the uniformity of the applied technology is a crucial factor when comparing products originating from different botanic forms.

The objective of the study was to compare the composition and nutritional value of double-low seeds, press-cake and solvent meal from yellow-seeded spring rape (Brassica rapa) and dark-seeded winter rape (Brassica napus) processed under the same technological conditions. Particular attention was paid to factors affecting energy value and utilization such as hull and tannin contents and digestibility of fibre fractions. The tests were performed with chickens and rats, which are considered to be a more suitable animal model for pigs than chickens because of more intensive fermentation of fibre in the large bowel.

\section{MATERIAL AND METHODS}

\section{Material}

Yellow-seeded spring rapeseed of Canadian var. Parkland (YSR) and darkseeded winter rapeseed (DSR), both from the 1996 harvest, and both of doublelow type, were processed industrially in an oil factory in Warsaw as described by

TABLE 2

Chemical composition of seeds, cake and meal of dark-seeded (DSR) and yellow-seeded (YSR) rape, \% DM

\begin{tabular}{|c|c|c|c|c|c|c|c|c|c|c|}
\hline Product & & $\begin{array}{c}\mathrm{DM} \\
\%\end{array}$ & $\begin{array}{l}\text { Crude } \\
\text { protein }\end{array}$ & $\begin{array}{l}\text { Crude } \\
\text { fat }\end{array}$ & Ash & ADF & NDF & $\mathrm{DF}$ & $T^{*}$ & $\underset{* *}{\mathrm{GLS}}$ \\
\hline \multirow[t]{3}{*}{ DSR } & Seeds & 93.8 & 20.1 & 46.6 & 4.1 & 11.4 & 14.2 & - & 0.27 & - \\
\hline & Cake & 93.3 & 28.6 & 22.9 & 5.9 & 16.5 & 20.5 & - & - & - \\
\hline & Meal & 89.2 & 35.6 & 3.0 & 7.4 & 20.7 & 25.8 & 35.8 & - & 20.9 \\
\hline \multirow[t]{3}{*}{ YSR } & Seeds & 92.9 & 21.2 & 45.8 & 4.2 & 8.9 & 13.5 & - & 0.26 & - \\
\hline & Cake & 92.0 & 30.6 & 23.2 & 6.2 & 12.6 & 19.1 & - & - & - \\
\hline & Meal & 88.9 & 38.1 & 4.8 & 7.4 & 15.6 & 23.7 & 33.1 &.- & 10.3 \\
\hline
\end{tabular}

* tannins in \% of fat-free DM

** glucosinolates in $\mu \mathrm{M} / \mathrm{g}$ fat-free DM 


\section{可}

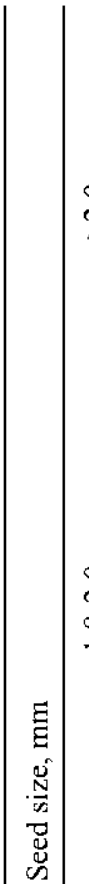

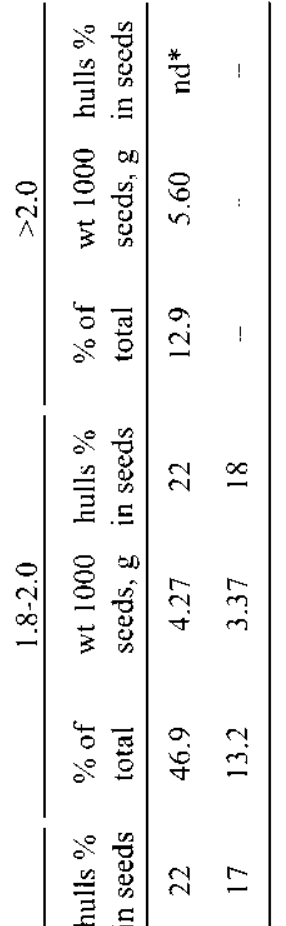

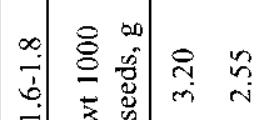

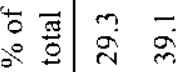
急峦 至.

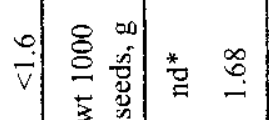

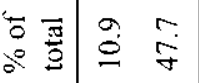

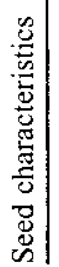

孚 㟧

래류 वे

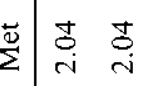

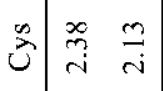

驾

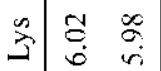

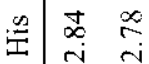

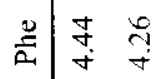

志吉

ᄅ

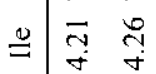

$\begin{array}{ll}F & n \\ \infty & n \\ n & n\end{array}$

$\underset{z}{z}$

ते $\begin{array}{ll}n & n \\ n & n\end{array}$

की

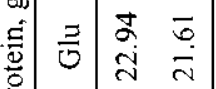

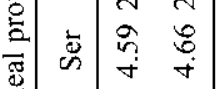

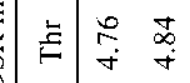

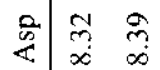

产

茨

:

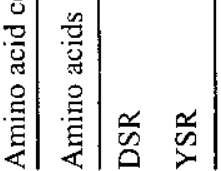


Mińkowski (1997). Samples of seeds were taken before processing, samples of cakes after pressing oil, while solvent meals represented the final commercial products after oil extraction and desolventizing (toasting). Seed dimensions were characterized and the chemical composition of all of the samples was evaluated (Tables 1,2 and 3).

\section{Experiments on chickens}

Experiment 1. Samples of YSR and BSR seeds, cakes and meals were finely ground. Apparent metabolizable energy value corrected for zero $\mathrm{N}$ balance $\left(A M E_{\gamma}\right)$ and apparent digestibility of protein and fat were determined on 63 three-week-old broiler cockerels according to the procedure described by Smulikowska et al. (1997).

Experiment 2. Growth performance on diets containing 20\% of YSR or BSR solvent extracted meals were compared. 198 broiler cockerels, maintained in pairs were divided into 3 groups and fed from the 8th day of life for 2 weeks on isoprotein and isoenergetic diets containing tested meals (Table 4), or soyabean oilmeal (control group). The glucosinolate content amounted to 3.60 and $1.73 \mu \mathrm{M} / \mathrm{g}$ of respective DSR and YSR diets. After the conclusion of the experiment 10 chickens from each group were killed, the thyroids were excised and immediately weighed.

TABLE 4

Composition of basal diet* (Experiments 1 and 5) and diets** in Experiment 2, g/kg

\begin{tabular}{lcccc}
\hline Ingredients & Basal diet* & Control** & DSR** & YSR** \\
\hline Rapeseed meal & - & - & 200 & 200 \\
Soyabean meal & 280 & 300 & 185 & 170 \\
Wheat & 667 & 603 & 499 & 517 \\
Soya oil & 10 & 60 & 79 & 76 \\
Mineral-vitamin premix*** & 43 & 37 & 37 & 37 \\
\hline
\end{tabular}

*** containing $(\mathrm{g} / \mathrm{kg})$ in Experiments 1 and 5: limestone 14; dicalcium phosphate $16 ; \mathrm{NaCl} 6$; mineral-vitamin premix 7; in Experiment 2: limestone 12; dicalcium phosphate 17; $\mathrm{NaCl} 3$; mineralvitamin premix 5

\section{Experiments on rats}

Experiments 3 and 4. Protein digestibility (TD), biological value (BV) and net protein utilization (NPU) of DSR and YSR cakes and meals were determined in a balance experiment on 28 twenty-ninc-day-old male rats. Growth performance was assayed on 28 twenty-five-day-old male rats during 21 days according to procedures described by Smulikowska et al. (1997). Diets were formulated to con- 
tain $9.5 \%$ of protein from evaluated rapeseed products, i.e. contained $35.6 ; 33.8$; 29.9 and $28.0 \%$ of DSR or YSR cakes and meals. The glucosinolate content amounted to 5.38 and $2.42 \mu \mathrm{M} / \mathrm{g}$ of diets containing DSR and YSR meals, respectively. After conclusion of the growth experiment, all rats were killed, the livers and thyroids were excised and immediately weighed.

Experiment 5. Digestible and metabolizable energy value of DSR and YSR seeds, cakes and meals were determined by the difference method on 84 rats weighing about $120 \mathrm{~g}$, divided into 7 groups. Rats were fed ad libitum during 10 days either on the basal diet (Table 4) or on diets composed of the basal diet and evaluated rape seed products in a proportion of $6: 4$. After a 4 -day preliminary period, facces and urine were quantitatively collected during 6 days and their gross energy content was measured in samples pooled from two animals.

Experiment 6. The digestibility of ADF and NDF fractions of DSR and YSR seeds, cakes and meals was measured on six groups of rats weighing about $100 \mathrm{~g}$, 12 animals per treatment. The only source of fibre in the semisynthetic diets was (per kg) $330 \mathrm{~g}$ of meals or $400 \mathrm{~g}$ of seeds or cake; the diets also contained casein (22 to $30 \mathrm{~g}$ ), sucrose ( $120 \mathrm{~g}$ ), oil (up to $80 \mathrm{~g}$ ), minerals and vitamins according to requirement, and wheat starch up to $1000 \mathrm{~g}$. After 6 days of a preliminary period, faeces were collected during 8 days. Faeces from two animals were pooled and analyzed for ADF and NDF contents.

\section{Chemical and statistical analysis}

The YSR and DSR seeds were sieved through sieves of $1.6,1.8$ and $2.0 \mathrm{~mm}$ mesh. Mass of 1000 seeds and $w / w$ proportion of hulls in seeds within the fractions was determined (Table 1).

In rape seed products, diets and excreta, chemical composition was determined by standard methods (AOAC, 1994), gross energy by Parr adiabatic oxygen bomb calorimeter KL-10, NDF and ADF content according to Van Soest (1967) on a Fibcrtcc M (Tecator) apparatus. In meals, glucosinolates were analyzed by HPLC according to the ISO-9167 (1991) method, amino acids were assayed on a Beckman 6300 amino acid analyzer, methionine and tryptophan using the modified procedures described by Buraczewska and Buraczewski (1981), tannins according to Kuhla and Ebmeier (1981) and dietary fibre according to Asp at al. (1983). In chickens excreta crude fat was determined by ether extraction after acid hydrolysis, faecal $\mathrm{N}$ according to Ekman et al. (1949), chromic oxide was determined spectrophotometrically following wet ashing according to Hinsberg et al. (1953).

The results were subjected to two way analysis of variance. The significance of differences among groups was estimated by the Duncan multiple range test using "Statgraphic Plus" ver. 7 software. 


\section{RESULTS}

\section{Composition of YSR and DSR seeds and products}

The YSR seeds were smaller than DSR since about half of YSR seeds were in the fraction of less than $1.6 \mathrm{~mm}$ diameter and about half of the DSR seeds in the $1.8-2.00 \mathrm{~mm}$ fraction; within all fractions the specific weight of YSR was smaller than of DSR seeds (Table 1). The proportion of hulls in YSR and DSR sceds was not uniform: in the fraction of smaller YSR seeds it was slightly higher, in the larger seeds fraction it was lower than in the respective DSR fractions (Tablc 1).

YSR seeds, cake and meal contained more protein than the respective DSR products (Table 2), however the content of essential amino acids in protein in both meals was similar (Table 3 ). The tannin content in defatted seeds was similar in both types of rape. The DSR meal contained twice as much glucosinolates than YSR ( 20.9 vs. $10.3 \mu \mathrm{M} / \mathrm{g}$ fat-free DM, respectively). The fibre content in YSR seeds and products was lower than in DSR, the largest differences were found in ADF content, smaller in NDF and dietary fibre (Table 2).

\section{Digestibility of nutrients and protein and energy utilization by chickens and rats}

Apparent protein digestibility (APD) determined on chickens was highest in both cakes, in seeds it was lower $(\mathrm{P} \leq 0.001)$. The biggest difference was found between the APD of DSR and YSR meal ( 83.6 vs. $87.1 \%$, respectively). Fat digestibility was higher in YSR seeds and products, and distinctly lower in both meals. Organic matter retention, $\mathrm{AME}_{\mathrm{N}}$ values and energy metabolizability were greatest in seeds, followed by cake and meals $(\mathrm{P} \leq 0.001)$, the respective values for YSR were higher than for DSR. In all measured parameters the interaction between the type of rapeseed and treatment was highly significant, since treatment of YSR seeds affected the measured values less adversely than DSR (Table 5).

In the experiment with rats the protein in cakes was more digestible $(\mathrm{P} \leq 0.001)$ but had a lower $\mathrm{BV}$ value $(\mathrm{P} \leq 0.05)$ than in meals, irrespective of the type of rape, however the values of NPU integrating both protein digestibility and biological value were lower $(\mathrm{P} \leq 0.05)$ for DSR products (Table 7).

The digestible and metabolizable energy content and metabolizability of energy in rats was highest in seeds, followed by cakes and meals $(\mathrm{P} \leq 0.001)$, but there was no significant difference between DSR and YSR. The interaction between the type of rape and treatment was significant $(\mathrm{P} \leq 0.001)$, since due to consecutive steps of oil extraction the metabolizability of energy decreased less in YSR (by 7.3 and 9.9 percentage points) than in DSR (by 11 and 13.6, respectively). Crude fibre and ADF and NDF fractions of YSR seeds, cake and meal were digested by rats better $(\mathrm{P} \leq 0.001)$ than $\mathrm{DSR}$, the treatment effect was also highly significant, but did not differ between the two rapeseed forms (Table 8). 
TABLE 5

Effect of type of rapeseed and processing on organic matter retention (OMR) apparent protein digestibility (APD) and fat digestibility (FD) in $\%, \mathrm{AME}_{\mathrm{N}}(\mathrm{MJ} / \mathrm{kg} \mathrm{DM})$ and metabolizability of energy $\left(\mathrm{AME}_{\mathrm{\kappa}} / \mathrm{GE}, \%\right)$ in chickens. Experiment 1

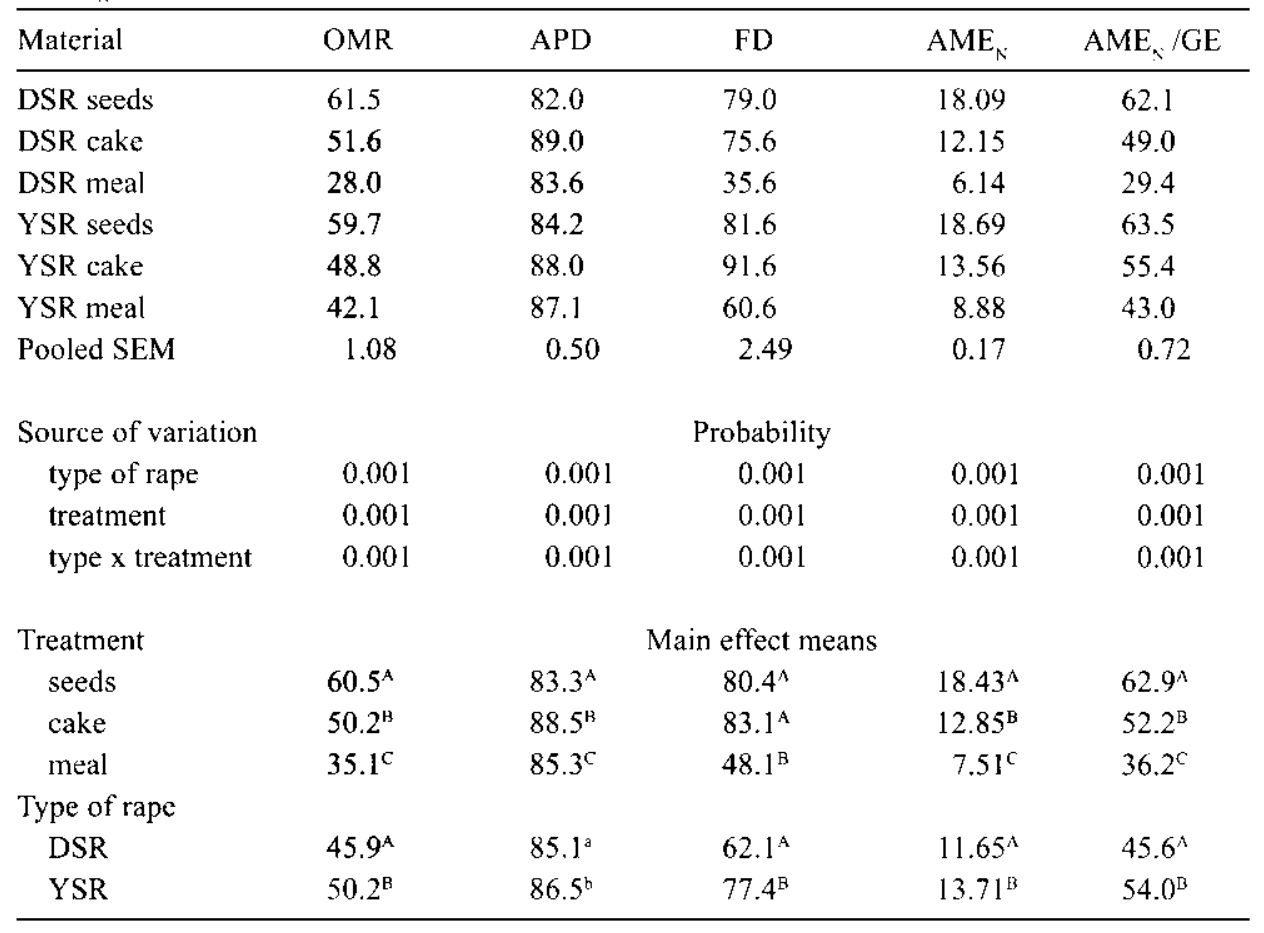

a, b, A, B - means with no common superseript differ significantly at: a,b - P $\leq 0.05 ; \mathrm{A}, \mathrm{B}-\mathrm{P} \leq 0.001$

TABLE 6

Performance of broiler cockerels (8-22 days) fed diets with DSR and YSR meals. Experiment 2

\begin{tabular}{lcccc}
\hline Item & \multicolumn{3}{c}{ Diet } & \multirow{2}{*}{ SEM } \\
\cline { 2 - 4 } & DSR & YSR & Control & \\
\hline Feed intake, g & 970 & 977 & 978 & 12.2 \\
Body weight gain, g & 656 & 660 & 665 & 11.8 \\
Feed/gain, g/g & 1.48 & 1.48 & 1.46 & 0.02 \\
Thyroid weight, $\mathrm{mg} / \mathrm{l} 00 \mathrm{~g} \mathrm{BW}$ & 8.37 & 8.52 & 7.34 & 0.74 \\
\hline
\end{tabular}

all differences were not significant 
Growth parameters of chickens and rats

In chickens fed for 14 days on isoenergetic and isoprotein dicts containing $20 \%$ DSR or YSR meal, neither feed intake nor growth rate were affected by type of rapeseed and did not differ from the results on control diet. Relative thyroid weight was 14 and $16 \%$ greater in birds on DSR and YSR meals than on the control diet, but due to large individual variance the differences did not reach the significance level (Table 6).

Rats fed both diets containing cakes ate significantly less food $(P \leq 0.001)$ and their growth rate was slower than on dicts with the respective meals $(P \leq 0.05)$, the feed intake and body weight gain were significantly lower $(\mathrm{P} \leq 0.05)$, while the relative thyroid and liver weight were higher in groups fed cakes than respective meals; relative thyroid $(\mathrm{P} \leq 0.001)$ and liver $(\mathrm{P} \leq 0.05)$ weight were greater in groups fed DSR than YSR products (Table 7). However, neither type of rape nor treatment significantly affected the feed conversion ratio in rats. The interaction

TABLE 7 Effect of type of rapeseed and processing on true protein digestibility (TD), biological value of protein (BV), net protein utilization (NPU) (Experiment 3) and performance of rats fed during 21 days on isoprotein diets containing DSR or YSR cake and meal (Experiment 4)

\begin{tabular}{|c|c|c|c|c|c|c|c|c|}
\hline Item & TD & BV & NPU & $\begin{array}{c}\text { Feed } \\
\text { intakeg }\end{array}$ & $\begin{array}{c}\text { BWG } \\
\mathrm{g}\end{array}$ & $\begin{array}{c}\text { FCR } \\
\mathrm{g} / \mathrm{g}\end{array}$ & $\begin{array}{c}\text { Thyroid } \\
\mathrm{mg} / 100 \\
\mathrm{~g} \mathrm{BW}\end{array}$ & $\begin{array}{l}\text { Liver } \\
\% \mathrm{BW}\end{array}$ \\
\hline DSR cake & 84.9 & 87.5 & 74.3 & 205.7 & 62.6 & 3.30 & 20.6 & 6.76 \\
\hline DSR meal & 80.1 & 90.6 & 72.5 & 256.5 & 77.8 & 3.33 & 10.6 & 5.60 \\
\hline YSR cake & 85.5 & 89.4 & 76.4 & 233.9 & 73.0 & 3.23 & 14.5 & 6.12 \\
\hline YSR meal & 81.8 & 91.6 & 75.0 & 271.5 & 87.0 & 3.16 & 8.7 & 5.38 \\
\hline Pooled SEM & 0.75 & 0.99 & 0.88 & 8.4 & 4.2 & 0.10 & 0.8 & 0.13 \\
\hline Source of variation & \multicolumn{8}{|c|}{ Probability } \\
\hline type of rape & 0.133 & 0.149 & 0.016 & 0.017 & 0.028 & 0.836 & 0.001 & 0.003 \\
\hline treatment & 0.001 & 0.013 & 0.077 & 0.001 & 0.002 & 0.217 & 0.001 & 0.001 \\
\hline type $x$ treatment & 0.439 & 0.634 & 0.879 & 0.448 & 0.887 & 0.633 & 0.016 & 0.114 \\
\hline Treatment & \multicolumn{8}{|c|}{ Main effect means } \\
\hline cake & $85.2^{\mathrm{A}}$ & $88.5^{\mathrm{a}}$ & $75.4^{\mathrm{a}}$ & $219.8^{\mathrm{A}}$ & $67.7^{\mathrm{a}}$ & $3.26^{\mathrm{a}}$ & $17.6^{4}$ & $6.44^{A}$ \\
\hline meal & $80.9^{\mathrm{B}}$ & $91.1^{\mathrm{b}}$ & $73.7^{a}$ & $264.0^{\mathrm{B}}$ & $82.4^{b}$ & $3.24^{\mathrm{a}}$ & $9.7^{\mathrm{H}}$ & $5.49^{\mathrm{B}}$ \\
\hline \multicolumn{9}{|l|}{ Type of rape } \\
\hline DSR & $82.5^{\mathrm{a}}$ & $89.0^{\mathrm{a}}$ & $73.4^{4}$ & $231.1^{4}$ & $70.2^{u}$ & $3.19^{\mathrm{a}}$ & $15.6^{A}$ & $6.18^{\mathrm{a}}$ \\
\hline YSR & $83.7^{a}$ & $90.5^{\mathrm{i}}$ & $75.7^{\mathrm{b}}$ & $252.7^{\mathrm{b}}$ & $80.0^{b}$ & $3.32^{: \prime}$ & $11.6^{\mathrm{B}}$ & $5.75^{\mathrm{b}}$ \\
\hline
\end{tabular}

a , b , A, B means with no common superscript differ significantly at: $a, b \ldots P \leq 0.05 ; A, B-P \leq 0.001$ 
TABLE 8

Digestible (DE) and metabolizable energy (ME) in $\mathrm{MJ} / \mathrm{kg} \mathrm{DM}$, metabolizability of energy (ME /GE, \%) (Experiment 5) and digestibility of crude (CF) acid detergent (ADF) and neutral detergent (NDF) fibre in $\%$ in rats (Experiment 6 )

\begin{tabular}{|c|c|c|c|c|c|c|}
\hline \multirow[t]{2}{*}{ Material } & \multirow[t]{2}{*}{$\mathrm{DE}$} & \multirow[t]{2}{*}{ ME } & \multirow[t]{2}{*}{$\mathrm{ME} / \mathrm{GE}$} & \multicolumn{3}{|c|}{ Digestibility, \% } \\
\hline & & & & $\mathrm{CF}$ & $\mathrm{ADF}$ & NDF \\
\hline DSR seeds & 20.81 & 20.11 & 69.0 & 77.0 & 62.8 & 67.2 \\
\hline DSR cake & 15.76 & 14.40 & 58.0 & 52.1 & 41.2 & 41.9 \\
\hline DSR meal & 10.62 & 9.25 & 44.4 & 29.3 & 30.4 & 39.5 \\
\hline YSR seeds & 19.67 & 19.07 & 64.8 & 82.9 & 74.3 & 73.0 \\
\hline YSR cake & 15.59 & 14.09 & 57.5 & 67.0 & 49.3 & 53.8 \\
\hline YSR meal & 11.56 & 9.83 & 47.6 & 37.0 & 36.1 & 48.0 \\
\hline Pooled SEM & 0.19 & 0.17 & 0.73 & 1.98 & 1.59 & 1.54 \\
\hline Source of variation & \multicolumn{6}{|c|}{ Probability } \\
\hline type of rapc & 0.564 & 0.106 & 0.574 & 0.001 & 0.001 & 0.001 \\
\hline treatment & 0.001 & 0.001 & 0.001 & 0.001 & 0.001 & 0.001 \\
\hline type $x$ treatment & 0.001 & 0.001 & 0.001 & 0.068 & 0.200 & 0.153 \\
\hline Treatment & \multicolumn{6}{|c|}{ Main effect means } \\
\hline seeds & $20.18^{A}$ & $19.54^{\mathrm{A}}$ & $66.7^{\mathrm{A}}$ & $80.0^{\mathrm{A}}$ & $68.6^{\mathrm{A}}$ & $70.1^{\mathrm{A}}$ \\
\hline cake & $15.67^{\mathrm{H}}$ & $14.25^{\mathrm{B}}$ & $57.8^{\mathrm{B}}$ & $59.6^{\mathrm{B}}$ & $45.3^{\mathrm{B}}$ & $47.8^{\mathrm{B}}$ \\
\hline meal & $11.09^{\mathrm{C}}$ & $9.54^{c}$ & $46.0^{c}$ & $33.2^{\circ}$ & $33.3^{\mathrm{C}}$ & $43.7^{\mathrm{B}}$ \\
\hline \multicolumn{7}{|l|}{ Type of rape } \\
\hline DSR & $15.43^{\mathrm{y}}$ & $14.26^{\mathrm{a}}$ & $56.4^{a}$ & $52.8^{A}$ & $44.8^{\mathrm{A}}$ & $49.5^{\mathrm{A}}$ \\
\hline YSR & $15.60^{\mathrm{a}}$ & $14.33^{\mathrm{a}}$ & $56.6^{\mathrm{a}}$ & $62.3^{\mathrm{B}}$ & $53.3^{\mathrm{B}}$ & $58.2^{\mathrm{B}}$ \\
\hline
\end{tabular}

a, b, A, B - means with no common superscript differ significantly at: $\mathrm{a}, \mathrm{b}-\mathrm{P} \leq 0.05 ; \mathrm{A}, \mathrm{B}-\mathrm{P} \leq 0.001$

between the type of rapeseed and treatment was significant only for relative thyroid weight $(\mathrm{P} \leq 0.05)$. BWG was negatively correlated with relative thyroid weight (Figure 1).

\section{DISCUSSION}

The yellow-seeded rapeseed contained more protein and less fibre in the seeds, cake and meal. The difference between protein content of meals was of a similar magnitude while that of dietary fibre agreed with the data of Słominski et al. (1994) but was much smaller than reported by Słominski (1997). The condensed tannin concentration in defatted seeds of both types was similar, and was lower than that found by Chibowska et al. (1994) in the commercial meal from winter dark-seeded rape. 


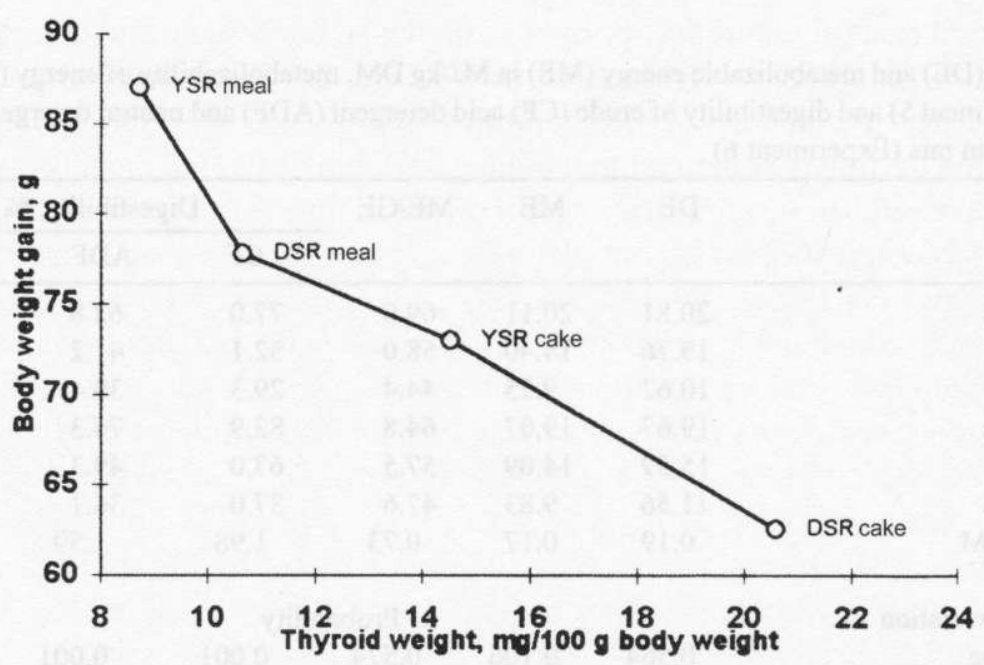

Figure 1. Relationship between body weight gain and thyroid weight of rats fed on diets with DSR and YSR cakes and meals

Seed size is an important factor affecting the proportions of hulls in seeds and consequently the concentration of fibre and protein in meals, the greater the specific weight of seeds the smaller fibre content (Jensen et al., 1995; Yong-Gang Liu et al., 1995). In the reported study the relationship between seed size and hull proportion was not observed in DSR since in the range from 3.2 to $5.6 \mathrm{~g}$ per 1000 seeds, the proportion of hulls was similar ( 23 to $22 \%$, respectively), whereas it was more distinct in YSR seeds, which weighed from 1.7 to $3.4 \mathrm{~g}$ per 1000 seeds and the proportion of hulls ranged from 25 to $17 \%$, respectively. The prevalence of smaller seeds with a greater proportion of hulls in YSR may account for the relatively small difference in NDF and DF content between two rapeseed forms. Protein, ash, NDF and ADF fibre content of yellow-seeded rapeseed was very close to that determined by Ochodzki and Piotrowska (1997) in the same material. These authors reported that yellow forms of rapeseed contain a smaller lignin and slightly greater cellulose proportion in fibre than brown-seeded ones.

The glucosinolate content was very high in DSR meal $(18 \mu \mathrm{M} / \mathrm{g})$. The level of glucosinolates has not been measured in the respective seeds but it may be supposed that it exceeded the upper limits for seeds qualified as low glucosinolate $(25 \mu \mathrm{M} / \mathrm{g})$, since in the process of oil extraction a substantial proportion of GLS is usually removed. The level of GLS in YSR meal was lower and within the limits for low glucosinolate varieties.

In both animal species used in our study, protein digestibility was slightly higher for YSR than DSR seeds and products, however the differences were not substantial. Similar results were found also by Ochodzki and Rakowska (1996) in 
rats. In chickens, protein digestibility was higher in both cakes and meals than in seeds. This is in agreement with the in vitro studies of Słominski (1997) showing that moist heat treatment with temperatures not exceeding $108^{\circ} \mathrm{C}$ applied for a short period of time is beneficial to the digestibility of rapeseed meal protein. The type of rapeseed had no significant effect on the biological value of protein, since amino acid composition of both forms was very similar. It increased as the result of processing (BV of cake protein was 88.5 and meal 91.1 on average). The net protein value, which integrates both protein content and utilization, was greater in YSR than in DSR products by about 2 percentage points.

Chickens digested the oil contained in YSR seeds slightly better than that in DSR seeds, the difference in fat digestibility between YSR and DSR products increased substantially as the oil content in cakes and meals diminished due to extraction, and amounted to 25 percentage points in meals. This pattern was followed by the differences in $\mathrm{AME}_{x}$ value and energy metabolizability between YSR and DSR sceds and products. The highly significant interaction between the effect of treatment on two types of rapeseed may indicate that the processing conditions negatively affect nutritional value of DSR rapeseed to a greater extent, or that the cell walls of DSR rape, encapsulating oil inside, are less prone to digestion/fermentation by bacterial enzymes in the chicken gastrointestinal tract than YSR cell walls. The dietary fibre digestibility from the balance experiment on chickens is not given in this paper since we obtained negative values.

In rats, a considerable portion of crude and detergent fibre was digested/fermented, the ratio was higher in YSR, lower in DSR seeds and products. The products of fermentation may be partially utilized by rats, since metabolizable energy measured on rats was from 0.53 (YSR cake) to 3.11 (DSR meal) $\mathrm{MJ} / \mathrm{kg}$ DM higher than in chickens. However, in rats the differences in fibre digestibility between YSR and DSR seeds and products were not reflected in their digestible and metabolizable energy content, which were of comparable value for both types of rape seed. It may be concluded that in rats, despite high digestibility coefficients of crude and detergent fibre, only a small portion of fibre may be transformed to particles available to the animal. However, as a result of bacterial fermentation, the cell walls may be partially destroyed and cell content more susceptible to digestion by enzymes of the digestive tract.

The growth response of chicken and rats fed diets containing DSR and YSR cake and/or meal was different. In chickens, despite different glucosinolate contents in DSR and YSR diets, feed intake, growth rate and feed conversion were similar and not different from performance of chickens fed control diets of the same protein and energy concentration. The lack of differences might result from too short observation, since thyroid weight, albeit larger in groups fed rapeseed meal-containing diets, did not differ significantly from the control group. In our previous experiment (Smulikowska et al., 1990) after three weeks of feeding the 
diet of a similar glucosinolate content as the DSR-containing diet in the present experiment, thyroid weight was three times as large as in the control group and BWG was negatively affected.

The higher glucosinolate level in DSR cake and meal caused enlargement of the thyroid and liver of rats, and a highly significant difference was also found between groups fed cake and meal of the same type. It negatively affected feed intake and growth rate but not feed conversion ratio. There was a close negative relationship between body weight gain and relative thyroid weight (Figure 1). The negative effect of glucosinolates on the performance of growing animals is well established (for review sec Mawson et al., 1994 and Rakowska, 1997). The observed difference between the responses of chickens and rats may be partly explained by the higher glucosinolate concentration in rat diets as well as the importance of intestinal microflora in glucosinolate toxicity (Bell, 1993). Digestion of a considerable proportion of dietary fibre in rats and lack of fibre digestion in chicken points to higher activity of microflora in the rat digestive tract. Active microflora may not only release glucosinolates and myrosinase connected with dietary fibre, but can also hydrolyze glucosinolates within the gastrointestinal tract of the rat (Rakowska, 1997), producing toxic metabolites.

\section{CONCLUSIONS}

The results confirm the data on greater protein and lower fibre content in yellow-seeded than in dark-seeded rapeseed, but the differences were of a small magnitude. Due to the higher protein content and marginally better protein utilization, cake and meal of yellow-seeded rape may be considered a more valuable protein source than the dark-seeded onc. The energy value $\left(A M E_{\mathrm{f}}\right)$ of yellow-seeded products is greater for chickens (but not for rats) mainly due to greater fat digestibility.

Deterioration of growth performance correlated in rats with the increased glucosinolate content in the evaluated products points to the importance of continuous efforts to keep the glucosinolate content in rapeseed as low as possible, and supports our previous observations (Smulikowska et al., 1997) that the nutritional value of rapeseed cakes may vary considerably.

\section{ACKNOWLEDGEMENTS}

Authors thank Grzegorz Jabłecki from the WZPT oil factory in Warsaw (Poland) for supplying the samples of rape seeds and products. 


\section{REFERENCES}

AOAC, 1995. Officia! Methods of Analysis of the Association of Official Analytical Chemists. 16th Edition. Washington, DC

Asp N.G., Johansson C.C., Halmer H., Siljestrom M., 1983. Rapid enzymatic assay of insoluble and soluble dietary fibre. J. Agric. Food Chem. 31, 476-482

Bell J.M., 1993. Factors affecting the nutritional value of canola meal. A review. Can. J. Anim. Sci. $73,679-697$

Buraczewska L., Buraczewski S., 1981. A note on the determination of methionine and tryptophane. Proceedings of 6th International Symposium on Amino Acids, Serock (Poland), pp. 47-50

Campbell L.D., Simbaya J., Zhang W., Słomiński B.A., Guenter W., 1995. Nutritive value of dehulled canola meal. Proceedings of 9th International Rapeseed Congress, Cambridge (UK), pp. 179-181

Chibowska M., Smulikowska S., Pastuszewska B., Alloui O., 1994. Factors affecting the metabolizable energy content of low glucosinolate rapeseed oil meal and its fractions. Proceedings of 9th European Poultry Conference, Glasgow (UK), pp. 523-524

Ekman P., Emanuelson H., Fransson A., 1949. The digestibility of protein in poultry. KGL. Lantbruks.-Hogskol. Ann. 16, 749

Hinsberg K., Cremer H. D., Schmid G., 1953. In: Hoppe-Seyler/Thierfelder-Handbuch der Physiologisch-und Patologisch-Chemischen Analyse. Springer-Verlag, Vol. 5, pp. 402-403

ISO-9167-1, Polish Standard, 1991. HPLC Method of Glucosinolates Determination (in Polish)

Jensen S.K., Yong-Gang Liu, Eggum B.O., 1995. The influence of seed size and hull content on the composition and digestibility of rapeseeds in rats. Anim. Feed Sci. Technol. 54, 9-19

Krzymański J., 1993. Possibilities to take full advantage of the quality of double low oilseed rape (in Polish). Post. Nauk rol. 40 (6), 161-166

Kuhla S., Ebmeier Ch., 1981. Untersuchungen zum Tanningehalt in Ackerbohnen. Arch. Tỉerernähr. $31,573-588$

Mawson R., Heaney R.K., Zduńczyk Z., Kozłowska H., 1994. Rapeseed meal-glucosinolates and their antinutritional effects. Part 3. Animal growth and performance. Nahrung 38, 167-177

Mińkowski K., 1997. Industrial processing of yellow seeded turning rape Brassica campestris. Observations and measurements (in Polish). Oilseed Crops 18, 505-510

Ochodzki P., Piotrowska A., 1997. Variation of chemical composition of defatted rape seeds selected for low fibre content (in Polish). Oilseed Crops 18, 511-524

Ochodzki P., Rakowska M., 1996. Comparison of chemical composition and nutritional value of dark- and yellow-seeded defatted rape (in Polish). Oilseed Crops 17, 477-482

Rakowska M., 1997. Chemical and biological properties of rapeseed glucosinolates (in Polish). Biul. inf. IHAR 201, 373-384

Słomiński B.A., 1997. Developments in the breeding of low fibre rapeseed/canola. J. Anim. Feed Sci. 6, 303-317

Słominiski B.A., Campbell L.D., Guenter W., 1994. Carbohydrates and dietary fibre components of yellow- and brown-seeded canola. J. Agric. Food Chem. 42, 704-707

Słomiński B.A., Simbaya J., Campbell L.D., Guenter W., Rakow G., 1995. Nutritive profile of yellow-seeded canola/rapeseed. Proceedings of 9 th International Rapeseed Congress, Cambridge (UK), Vol. 1, pp. 148-150

Smulikowska S., Chibowska M., Wiśniewska J., 1990. Effects of low glucosinolate rape seed - raw, pressed or extracted on performance, thyroid status and fatty acid profile of broiler chicken. Proceedings of 8 th European Poultry Conference. Barcelona (Spain), pp. 348-351 
Smulikowska S., Pastuszewska B., Mieczkowska A., Ochtabińska A., 1997. Chemical composition, energy value for chickens, and protein utilization in rats of rapeseed expeller cakes produced by different pressing technologies. J. Anim. Feed Sci. 6, 109-121

Van Soest P.J., Wine R.H., 1967. Use of detergents in the analysis of fibrous feeds. IV. Determination of plant cell-wall constituents. J. Assoc. Off. Agric. Chem. 50, 50-55

Statgraphics Plus ver.7., 1993. Statistical Grafics System by Graphics Corporation

Yong-Gang Liu, Jensen S.K., Eggum B.O., 1995. The influence of seed size on digestibility and growth parameters of broiler chickens fed full-fat rapeseed. J. Sci. Food Agric. 67, 135-140

\section{STRESZCZENIE}

Sklad chemiczny i wartość pokarmowa nasion, wytloków i śruty poekstrakcyjnej z żỏłtonasiennego rzepaku jarego i ciemnonasiennego rzepaku ozimego typu podwójnie ulepszonego

Oznaczono skład chemiczny i wartość pokarmową nasion, wytłoków i śruty poekstrakcyjnej, wyprodukowanych w tych samych warunkach technologicznych z żółto-nasiennego rzepaku jarego (YSR) i ciemno-nasiennego rzepaku ozimego (DSR), typu podwójnie ulepszonego. Produkty YSR zawierały więcej białka i mniej włókna, śruta zawierała podobną ilość tanin i aminokwasów ( $\mathrm{g} / 16 \mathrm{~g} \mathrm{~N})$, lecz o połowę mniej glukozynolanów niż DSR.

Wartość odżywczą badano w 2 doświadczeniach na 261 kogutkach brojlerach i w 4 doświadczeniach na 212 szczurach samcach. W doświadczeniu na kurczętach wartość energetyczna wszystkich produktów YSR była istotnie większa niż DSR, na co główny wpływ miała lepsza strawność thuszczu. W doświadczeniach na szczurach wartość odżywcza białka (TD, BV, NPU) i zawartość energii metabolicznej w wytłoku i śrucie YSR nie różniły się lub były nieznacznie większe niż w odpowiednich produktach DSR.

Przyrosty masy ciała i wykorzystanie paszy u kurcząt otrzymujących izoenergetyczne diety zawierające $20 \%$ śrut YSR lub DSR nie różniły się od odpowiednich wskaźników w grupie kontroInej. U szczurów spożycie paszy, a co za tym idzie przyrost masy ciała, były ujemnie skorelowane z zawartością glukozynolanów w badanych paszach i znacznie większe przy podawaniu diet zawierajacych wytłok lub śrutę YSR. 